\title{
THE PRODUCTION OF GAMMA-GLOBULIN IN THE CENTRAL NERVOUS SYSTEM
}

\author{
BY \\ E. O. FIELD \\ From the Courtauld Institute of Biochemistry, Middlesex Hospital, London, W.1, \\ and the Department of Biochemistry (Radcliffe Infirmary), University of Oxford
}

The bulk of the cerebrospinal fluid proteins are by physico-chemical (Booy, 1949, 1950 ; Kabat, Landow, and Moore, 1942 ; Kabat, Moore, and Landow, 1942) and immuno-chemical (Kabat, Glusman, and Knaub, 1948 ; Kabat, Freedman, Murray, and Knaub, 1950) criteria identical with the serum proteins. Apart, however, from being present in considerably lower total concentration the various components do not occur in the same proportions in the cerebrospinal fluid and in the serum. Albumin is preponderant in the cerebrospinal fluid and $\alpha$ - and $\beta$-globulins are present in amounts which may in normal subjects be too low to be detected. Alterations are found both in the total protein concentration of the cerebrospinal fluid and in the relative concentrations of the components in disease affecting the central nervous system. Bing and Neel (1942) have reviewed the earlier studies on albumin/globulin ratios obtained by salting-out techniques. These indicated a relative increase in the globulin fraction in chronic inflammatory diseases such as disseminated sclerosis and neurosyphilis. More detailed electrophoretic and immuno-chemical studies have shown that the increase in this fraction is due to $\gamma$-globulin.

Bing and Neel (1942) also pointed out that a characteristic feature of the lesions in these diseases is the accumulation of plasma cells in the central nervous system. Since the production of $\gamma$-globulin appears to be a function of the reticulo-endothelial system, in particular of plasma cells, and since antibodies are associated with $\gamma$-globulin (see review by Burnet and Fenner, 1949) it would be of interest to ascertain the extent, if any, to which the $\gamma$-globulins in the cerebrospinal fluid are produced in the central nervous system. That antibodies may be produced there has been suggested by clinical observations that positive Wassermann reactions may be found in the cerebrospinal fluid when the reactions in the serum are negative and, recently, by the demonstration in monkeys of the production of antibody to poliomyelitis virus within the central nervous system (Morgan, 1947a and b ; Morgan, Howe and Bodian, 1947).

This paper describes the results of electrophoretic studies on the protein components of cerebrospinal fluids and sera in selected pathological conditions. The findings suggest that a proportion of the $\gamma$-globulin of the cerebrospinal fluid can be produced in the central nervous system.

\section{Experimental}

Principles.-The relative permeability of the bloodcerebrospinal fluid barrier to different serum proteins was investigated by comparing their concentrations in the serum and in the cerebrospinal fluid in three patients with multiple myeloma whose serum $\gamma$-globulin level was grossly raised. Four normal controls, 26 cases of disseminated sclerosis, and two of neurosyphilis were similarly investigated in order to determine whether (a) the concentrations of different protein components in the cerebrospinal fluid vary independently, and $(b)$ the proportion of $\gamma$-globulin in these diseases is significantly higher than would be expected from a study of the cases of multiple myeloma.

Lastly, four normal, Mantoux-positive subjects who had received intrathecal tuberculin were investigated. The reaction evoked comprises two phases, both associated with an increase in the cell count and protein content of the cerebrospinal fluid. The first phase, in which the cells are largely polymorphonuclear, reaches a maximum in $\mathbf{2 4}$ hours, and is followed by a short remission. In the second phase, which reaches a maximum between the fourth and seventh day and is more prolonged, the cells are lymphocytes. It was thus possible in these subjects to follow the changes from an acute to a chronic stage. These studies were conducted as part of the work on tuberculous meningitis described by Swithinbank, Smith, and Vollum (1953).

Methods.-Total protein concentrations of all sera and of the cerebrospinal fluids from the subjects receiving intrathecal tuberculin were determined refractometrically. Those of the remaining cerebrospinal fluids were determined turbidometrically (to the nearest $5 \mathrm{mg}$./ $100 \mathrm{ml}$.) or by a modified micro-Kjeldahl technique. 
Protein analyses were performed electrophoretically in phosphate buffers of $p \mathrm{H} \cdot \mathbf{8 \cdot 0}$. The concentrations of the buffers were such that approximately the same protein/ buffer ratio was always obtained, since this ratio affects to some extent the analytical results (Perlmann and Kaufman, 1945). Thus, the buffer concentrations were $\mathbf{M} / 15$ for sera, $\mathbf{M} / 30$ for cerebrospinal fluids from the cases receiving intrathecal tuberculin, and $M / 60$ for all other cerebrospinal fluids.

Sera were diluted 1 in 6 with buffer and dialysed against further volumes of buffer. Cerebrospinal fluids, about $20 \mathrm{ml}$. from each patient, were first dialysed against buffer in order to eliminate non-protein nitrogen and to introduce buffer. They were then concentrated to approximately one fifth (for the cases of intrathecal tuberculin) or one tenth of their original volumes (for all other cases) by dialysing against $50 \%$ gum arabic solution (Ewerbeck, 1950) and finally redialysed against buffer. With each fluid all these operations were carried out in the same dialysis bag, at 0 to $5^{\circ} \mathrm{C}$. This has the advantage over methods depending on evaporation or ultra-filtration in that changes due to denaturation and adsorption on surfaces are reduced to a minimum.

Electrophoresis was carried out in the Tiselius (1937) apparatus, employing the diagonal Schlieren and cylindrical lens optical system. Measurements of areas were obtained from tracings of enlargements of the photographed patterns. With cerebrospinal fluids of low protein content a preliminary photograph, with the same exposure and magnification, was taken immediately on forming the boundaries in order to correct for baseline distortion at high magnification. Values for the negative (descending) limb only were used in the analyses of results since it was often found with cerebrospinal fluids that the $\delta$-boundary in the ascending limb was not sufficiently separated from the $\gamma$-globulin boundary.

\section{Results}

Multiple Myeloma.-The results of the three cases investigated are shown in Table I. On comparing
TABLE I

CEREBROSPINAL FLUID AND SERUM PROTEIN COMPONENTS IN MULTIPLE MYELOMA

\begin{tabular}{|c|c|c|c|c|c|c|}
\hline \multirow{2}{*}{ Case } & \multirow{2}{*}{$\begin{array}{c}\text { Total } \\
\text { Protein } \\
\text { (g./100 } \\
\text { ml.) }\end{array}$} & \multicolumn{3}{|c|}{$\begin{array}{c}\text { Protein Fractions as } \% \text { of } \\
\text { Total Proteins }\end{array}$} & \multirow{2}{*}{$\begin{array}{c}\text { Albumin } \\
\gamma-\text { Glo- } \\
\text { bulin }\end{array}$} & \multirow{2}{*}{$\mathbf{R}_{\mathbf{B}} / \mathbf{R}_{\mathbf{c}}{ }^{\dagger}$} \\
\hline & & Albumin & $\begin{array}{l}(\alpha+\beta)- \\
\text { Globulin }\end{array}$ & $\begin{array}{c}\gamma \text {-Glo- } \\
\text { bulin }\end{array}$ & & \\
\hline 26 & $\begin{array}{l}0.045 \\
10 \cdot 6^{*}\end{array}$ & $\begin{array}{l}47 \cdot 9 \\
23 \cdot 0\end{array}$ & $\begin{array}{l}15 \cdot 4 \\
10 \cdot 8\end{array}$ & $\begin{array}{l}36 \cdot 7 \\
66 \cdot 2\end{array}$ & $\begin{array}{l}1 \cdot 3 \\
0 \cdot 35\end{array}$ & $0 \cdot 27$ \\
\hline 44 & $\begin{array}{r}0 \cdot 048 \\
14 \cdot 2\end{array}$ & $\begin{array}{l}39 \cdot 3 \\
16 \cdot 7\end{array}$ & $\begin{array}{r}12 \cdot 8 \\
4 \cdot 5\end{array}$ & $\begin{array}{l}42 \cdot 9 \\
78 \cdot 9\end{array}$ & $\begin{array}{l}0.91 \\
0.21\end{array}$ & $0 \cdot 23$ \\
\hline 45 & $\begin{array}{r}0.051 \\
7.5\end{array}$ & $\begin{array}{l}72 \cdot 0 \\
51 \cdot 5\end{array}$ & $\begin{array}{r}5.9 \\
21 \cdot 8\end{array}$ & $\begin{array}{l}14 \cdot 7 \\
24 \cdot 5\end{array}$ & $\begin{array}{l}4 \cdot 9 \\
2 \cdot 1\end{array}$ & 0.43 \\
\hline
\end{tabular}

*Serum concentrations in italics.

$+R_{s}$ and $R_{c}$ are albumin $\gamma$-globulin ratios of the serum and cerebrospinal fluid respectively.

the albumin $/ \gamma$-globulin ratio of the serum with that of the cerebrospinal fluid $\left(\mathbf{R}_{\mathrm{s}} / \mathbf{R}_{\mathrm{c}}\right.$ value in the table), it will be seen that the blood-cerebrospinal fluid barrier was respectively $0.27,0.23$, and 0.43 times as permeable to $\gamma$-globulin as to albumin if it is assumed that both components were derived predominantly from the serum.

Controls, Disseminated Sclerosis, and Neurosyphilis.-In Table II cases of disseminated sclerosis and neurosyphilis are presented in groups according to the total amount of protein found in the cerebrospinal fluid. This table shows that $\mathbf{R}_{\mathrm{s}} / \mathbf{R}_{\mathrm{c}}$ values are considerably increased at the higher total protein concentrations.

In Fig. 1 the cerebrospinal fluid concentrations of $(\alpha+\beta)$-globulin and of $\gamma$-globulin have been plotted against those of albumin. There is a discernible tendency for a linear relationship between albumin and $(\alpha+\beta)$-globulin (correlation coefficient $0 \cdot 76$ ) but this relationship is less noticeable between

TABLE II

CEREBROSPINAL FLUID AND SERUM PROTEIN COMPONENTS IN DISSEMINATED SCLEROSIS, NEUROSYPHILIS, AND CONTROLS

\begin{tabular}{|c|c|c|c|c|c|c|c|c|c|c|c|c|c|}
\hline \multicolumn{8}{|c|}{ Cerebrospinal Fluids } & \multicolumn{5}{|c|}{ Sera } & \multirow[b]{2}{*}{$\mathbf{R}_{\mathrm{B}} / \mathbf{R}_{\mathrm{c}}$} \\
\hline Jroup & Diagnosis & $\begin{array}{c}\text { No. } \\
\text { of } \\
\text { Cases }\end{array}$ & $\begin{array}{l}\text { Total } \\
\text { Protein } \\
\text { (mg./ } \\
100 \mathrm{ml} .)\end{array}$ & $\begin{array}{l}\text { Albumin } \\
\text { (mg./100 } \\
\text { ml.) }\end{array}$ & $\begin{array}{c}\alpha+\beta \\
\text { Globulin } \\
\text { (mg./100 } \\
\text { ml.) }\end{array}$ & $\begin{array}{c}\gamma \text {-Glo- } \\
\text { bulin } \\
(\mathrm{mg} . / 100 \\
\text { ml. })\end{array}$ & $\begin{array}{c}\text { Albumin } \\
\gamma-\text { Glo- } \\
\text { bulin } \\
\text { (mg./100 } \\
\text { ml.) }\end{array}$ & $\begin{array}{l}\text { Total } \\
\text { Protein } \\
\text { (g./100 } \\
\text { ml.) }\end{array}$ & $\begin{array}{c}\text { Albumin } \\
(\mathrm{g} . / 100 \\
\mathrm{ml} .)\end{array}$ & $\begin{array}{c}\alpha+\beta \\
\text { Globulin } \\
\text { (g. } 100 \\
\text { ml.) }\end{array}$ & $\begin{array}{c}\text { r-Glo- } \\
\text { bulin } \\
\text { (g./100 } \\
\text { ml.) }\end{array}$ & $\begin{array}{c}\text { Albumin } \\
\gamma \text {-Glo- } \\
\text { bulin } \\
(\mathrm{g} \cdot 100 \\
\text { ml. })\end{array}$ & \\
\hline 1 & Controls & 4 & $25-30 \cdot 4$ & $17 \cdot 9 \pm 2 \cdot 4$ & $4 \cdot 5 \pm 1 \cdot 6$ & $3 \cdot 7 \pm 1 \cdot 3$ & $6 \cdot 2 \pm 4 \cdot 0$ & $7.91 \pm 0.41$ & $4 \cdot 65 \pm 0 \cdot 37$ & $2 \cdot 15 \pm 0.58$ & $1 \cdot 11 \pm 0.22$ & $4 \cdot 2 \pm 1 \cdot 0$ & $0.87 \pm 0.36$ \\
\hline 2 & $\begin{array}{l}\text { Disseminated } \\
\text { sclerosis }\end{array}$ & 5 & $15-25$ & $14 \cdot 1 \pm 2 \cdot 9$ & $3 \cdot 0 \pm 1 \cdot 6$ & $3.9 \pm 0.9$ & $3 \cdot 9 \pm 1 \cdot 5$ & $7 \cdot 43 \div 0.35$ & $4.50 \div 0.59$ & $1 \cdot 60 \pm 0.27$ & $1.53 \pm 0.20$ & $3 \cdot 9 \pm 1 \cdot 8$ & $0.98 \pm 0.24$ \\
\hline 3 & $\begin{array}{l}\text { Disseminated } \\
\text { sclerosis }\end{array}$ & 10 & $25 \cdot 1-35$ & $18 \cdot 8 \pm 3 \cdot 6$ & $4 \cdot 0 \pm 1 \cdot 2$ & $5 \cdot 8 \div 1 \cdot 5$ & $3.9 \div 0.97$ & $7 \cdot 26 \pm 0 \cdot 81$ & $4.58 \pm 0.49$ & $1.62 \pm 0.26$ & $1 \cdot 12 \pm 0.29$ & $4 \cdot 3 \pm 0.9$ & $1 \cdot 23 \pm 0.59$ \\
\hline 4 & $\begin{array}{l}\text { Disseminated } \\
\text { sclerosis }\end{array}$ & 5 & $35 \cdot 1-50$ & $26 \cdot 7 \pm 4 \cdot 5$ & $5 \cdot 9 \pm 1 \cdot 3$ & $12 \cdot 4 \pm 3 \cdot 1$ & $2 \cdot 4 \pm 1 \cdot 0$ & $7 \cdot 64 \pm 1 \cdot 23$ & $4.89 \pm 0.53$ & $1.53 \pm 0.41$ & $1 \cdot 22 \pm 0.37$ & $4 \cdot 5 \pm 1 \cdot 7$ & $2.06 \pm 0.54$ \\
\hline 5 & $\begin{array}{l}\text { Disseminated } \\
\text { sclerosis and } \\
\text { neurosyphilis }\end{array}$ & 5 & $50 \cdot 1-65$ & $36 \cdot 7 \pm 6 \cdot 3$ & $8 \cdot 5 \pm 2 \cdot 3$ & $13.8 \pm 5 \cdot 8$ & $3 \cdot 3 \pm 1 \cdot 7$ & $7 \cdot 25 \div 0.55$ & $4 \cdot 27 \pm 0 \cdot 24$ & $1.48 \pm 0.27$ & $1.51 \pm 0.62$ & $3 \cdot 2 \pm 1 \cdot 0$ & $1 \cdot 16 \pm 0.51$ \\
\hline 6 & $\begin{array}{l}\text { Disseminated } \\
\text { sclerosis and } \\
\text { neurosyphilis }\end{array}$ & 3 & $65 \cdot 1-80$ & $45 \cdot 2 \pm 1 \cdot 6$ & $10.9 \pm 0.7$ & $17 \cdot 4 \div 5 \cdot 4$ & $2 \cdot 9 \pm 0 \cdot 74$ & $7 \cdot 27 \div 0 \cdot 88$ & $4.59 \pm 0.68$ & $1 \cdot 60 \div 0 \cdot 11$ & $1 \cdot 07 \pm 0 \cdot 14$ & $4 \cdot 3 \pm 0 \cdot 5$ & $1.68 \pm 0.60$ \\
\hline
\end{tabular}


albumin and $\gamma$-globulin concentrations (correlation coefficient $0 \cdot 56$ ).

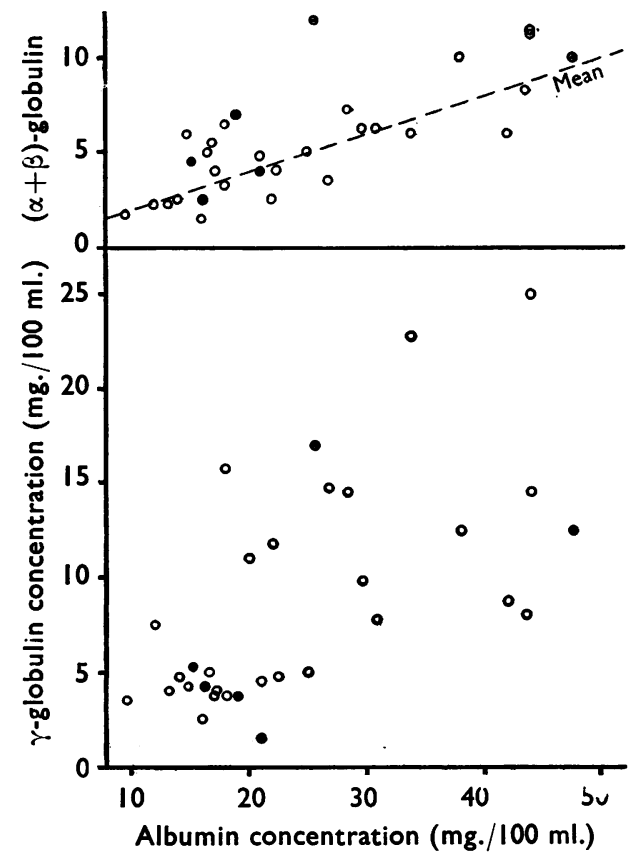

Fig. 1.-Cerebrospinal fluid albumin concentrations plotted against $(\alpha+\beta)$-globulin (above) and $\gamma$-globulin concentrations (below). Black circles represent normal controls; clear circles, disseminated sclerosis ; dotted circles, neurosyphilis.

Intrathecal Tuberculin.-Fig. 2 shows changes in the globulin components of the cerebrospinal fluid and of the serum in one subject over a period of three weeks. The globulin concentrations are expressed as a percentage of albumin rather than of total protein, since the cerebrospinal fluid albumin level is probably a better criterion of the permeability of the blood-cerebrospinal fluid barrier. The variations in the concentration of total protein are also given (heavy line) on a different scale in order to indicate the phases of the reaction.

The usual diphasic response in the total protein appears in each case, but in addition there is a consistent tendency for the $\gamma$-globulin/albumin ratio to rise during the second half of the first week coinciding with the "lymphocytic" second phase. From Fig. 2 it can be seen that these changes in the cerebrospinal fluid are not related to those in the serum. Of interest is the $\gamma$-globulin "spike" shown in Fig. 2 on the third day. This subject had received intrathecal tuberculin on a previous occasion and this reaction is reminiscent of an anamnestic response.

\section{Discussion}

It is remarkable that the correlation coefficient for cerebrospinal fluid $(\alpha+\beta)$-globulin and albumin concentrations (shown in Fig. 1) should be so high despite the errors of estimation at such low globulin concentrations, and the fact that the concentration of a protein in the cerebrospinal fluid depends to some extent on its concentration in the serum and that the relative permeability of the blood-cerebrospinal fluid barrier to the different proteins may vary from individual to individual. Since $(\alpha+\beta)$-globulin in the cerebrospinal fluid showed a greater tendency to vary in parallel with albumin than did $\gamma$-globulin, the conclusion may be drawn that the first two classes of protein have a common source, that is, both being derived from the serum, while a proportion at least of the $\gamma$-globulin originates independently within the central nervous system.

This conclusion gains support from the following additional considerations. The mean value for the cerebrospinal fluid/serum $\gamma$-globulin ratio in the cases of disseminated sclerosis and of neurosyphilis was found to be 1.4 times this ratio for albumin. Moreover, this figure was significantly higher for the cases with total proteins over $35 \mathrm{mg} . / 100 \mathrm{ml}$. $\left(R_{s} / R_{c}=1.62 \pm 0.67\right)$ than for those with lower total protein concentrations $\left(R_{s} / R_{c}=1 \cdot 15 \pm 0 \cdot 51\right)$, despite the possibility that the electrophoretic technique may give falsely high values for $\gamma$-globulin at very low concentrations. If these figures are compared with those obtained in the cases of multiple myeloma $\left(R_{s} / R_{c}=0.27,0.23\right.$, and 0.43$)$, it is evident either that the permeability of the blood-cerebrospinal fluid barrier is grossly disturbed in disseminated sclerosis and neurosyphilis, or that some $\gamma$-globulin is produced in the central nervous system in these diseases. It would, however, be difficult to explain how a simple increase in permeability of the blood-cerebrospinal fluid barrier could result in greater permeability to the $\gamma$-globulin than to the smaller albumin molecule.

Two of the patients with disseminated sclerosis had high serum antistreptolytic $O$ titres (480 and 700 respectively). It could be calculated from the corresponding cerebrospinal fluid serum $\gamma$-globulin ratios, that, were all cerebrospinal fluid $\gamma$-globulin derived from the serum, the antibody should have been detectable in the cerebrospinal fluid. None, however, could be detected in either case. Similar findings on the distribution of Brucella agglutinins have been reported by Spink and Kimball (1950).

In the subjects receiving intrathecal tuberculin the $\gamma$-globulin/albumin ratio again varied more than did the $\beta$-globulin/albumin ratio. ( $\alpha$-globulins 


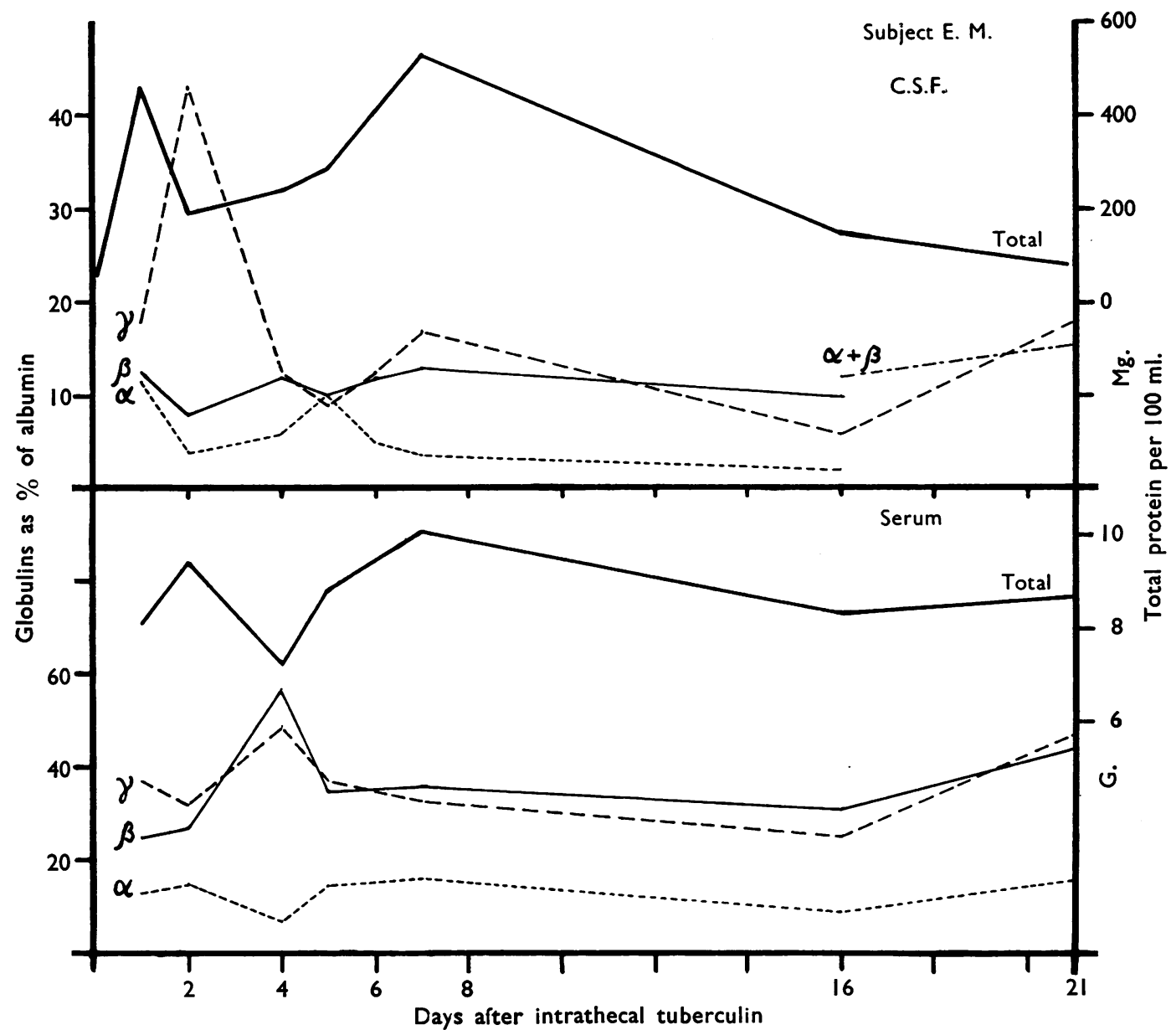

FIG. 2.-Changes in the concentrations of globulins (expressed as \% of albumin) in the cerebrospinal fluid and the serum in one subject following intrathecal tuberculin over a period of three weeks. Changes in the total proteins (heavy lines, plotted to scale at right) are also shown in order to indicate the phases of the reaction.

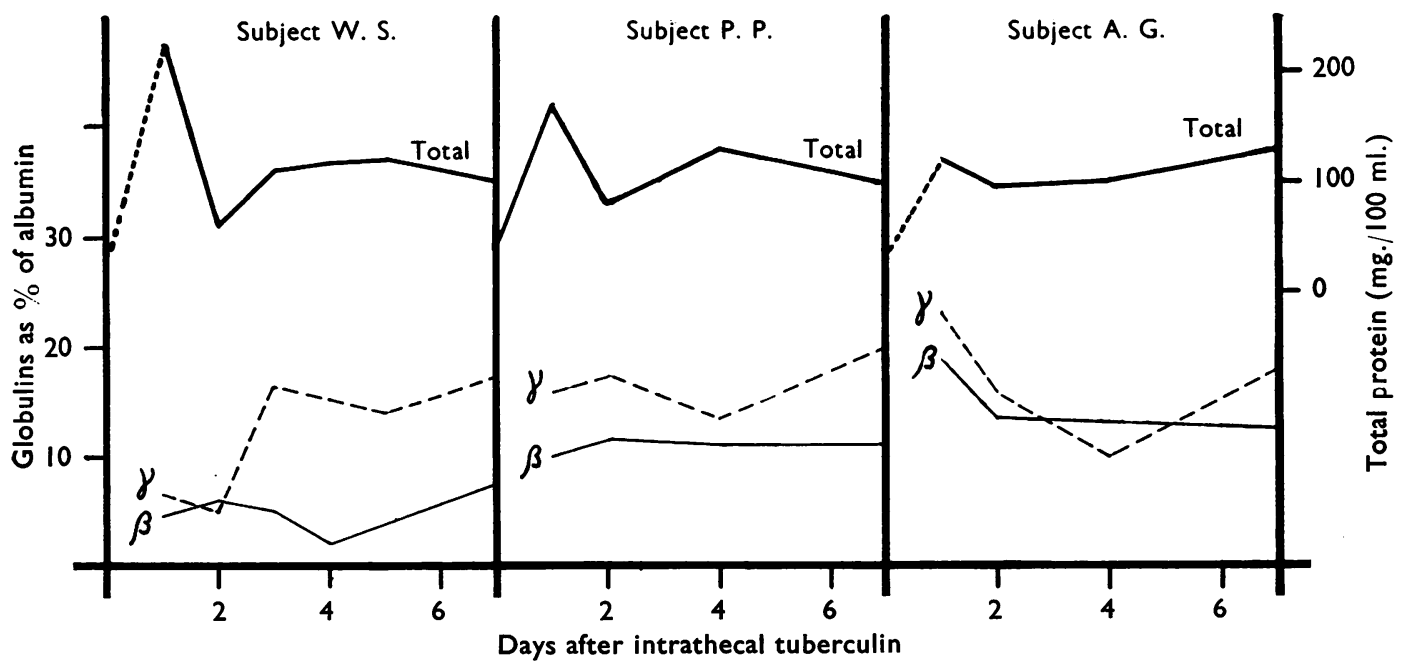

FIG. 3.-Changes in the concentrations of globulins and of total proteins in the cerebrospinal fluid in three subjects following intrathecal tuberculin, over a period of one week each. 
in the subjects shown in Fig. 3 were too low for useful inclusion.) The difference in the degrees of variation was significant at the $12 \%$ level of probability by the t-test which was applied to the mean difference between standard deviations of the two ratios computed for each of the four subjects. Hence, though not by themselves conclusive, these findings support the conclusions derived from the studies on disseminated sclerosis and neurosyphilis.

In 19 of the patients with disseminated sclerosis in whom lymphocyte counts of the cerebrospinal fluid were performed, the $\gamma$-globulin/albumin ratio was significantly higher if the cells numbered 2 or more per ml. (mean ratio $=4 \cdot 1 \pm .9$ ) than in the remainder (mean ratio $=2 \cdot 8 \pm 1 \cdot 2$ ). The rise in the proportion of $\gamma$-globulin in the cerebrospinal fluid in the cases receiving intrathecal tuberculin also appeared during the phase which was characterized by a high cerebrospinal fluid lymphocyte count. Since the production of $\gamma$-globulin in the body is associated with the reticulo-endothelial system, these findings suggest that the accumulations of lymphoid tissue in the central nervous system may be the source of the locally produced $\gamma$-globulin.

\section{Summary}

The cerebrospinal fluid and serum proteins have been studied electrophoretically in four normal controls, three cases of multiple myeloma, 26 of disseminated sclerosis, and two of neurosyphilis, and in four normal Mantoux-positive subjects receiving intrathecal tuberculin.

In chronic inflammatory disease of the central nervous system the $\gamma$-globulin/albumin ratio of the cerebrospinal fluid was found to be higher than that of the serum, and varied more than did the $(\alpha+\beta)$ globulin/albumin ratio.

It was concluded that in these diseases a proportion of the cerebrospinal fluid $\gamma$-globulin was produced in the central nervous system.

A rise in $\gamma$-globulin was found to be associated with a raised lymphocyte count in the cerebrospinal fluid.

I wish to express my gratitude to Professor E. C. Dodds, F.R.S., and to Mr. J. R. P. O'Brien for their support in this work, to Dr. D. McAlpine, under whose programme of disseminated sclerosis research part of the work was undertaken, to Dr. Honor Smith, and to Dr. Nigel Compston. Thanks are also due to Professor R. W. Scarff for data on antistreptolytic titres and cerebrospinal fluid lymphocyte counts.

\section{REFERENCES}

Bing, J., and Neel, A. V. (1942). Acta med. scand., 111, 57.

Booy, J. (1949). Folia psychiat., Amst., 52, 247.

Booy, (1950). Ibid., 53, 502.

Burnet, F. M., and Fenner, F. (1949). The Production of Antibodies, 2nd ed. Macmillan, London.

Ewerbeck, H. (1950). Klin. Wschr., 28, 692.

Kabat, E. A., Freedman, D. A., Murray, J. P., and Knaub, V. (1950). Amer. J. med. Sci., 219, 55.

Glusman, M., and Knaub, V. (1948). Amer. J. Med., 4, 653.

Landow, H., and Moore, D. H. (1942). Proc. Soc. exp. Biol., N.Y., 49, 260.

N.Y., 49, 260.
Moore, D. H., and Landow, H. (1942). J. clin. Invest., 21, 571.

Morgan, I. M. (1947a). J. exp. Med., 85, 131 .
Moore, D. H., and Landow, H. (1942). J.

Morgan, 197b). Amer. J. Hyg., 45, 390.

- Howe, H. A., and Bodian, D. (1947). Ibid., 45, 379.

Perlmann, G. E., and Kaufman, D. (1945). J. Amer. chem. Soc., $67,638$.

Spink, W. W., and Kimball, A. (1950). Proc. Soc. exp. Biol., N.Y., 73,67

Swithinbank, J., Smith, H. V., and Vollum, R. L. (1953). J. Path. Bact., 65, 565.

Tiselius, A. (1937). Trans. Faraday Soc., 33, 524. 